\title{
Ants as an Indicator of Restoration of Disturbed Areas (on the Example of Coal Industry Dumps, Kuzbass, Russia)
}

\author{
Svetlana Blinova ${ }^{1,}$, Sergey Luzyanin ${ }^{1}$, and Tatiana Dobrydina ${ }^{2}$ \\ ${ }^{1}$ Kemerovo State University, Department of Ecology and Nature Management, 650000, 6 Krasnaya \\ st., Kemerovo, Russian Federation \\ ${ }^{2}$ Kemerovo State University, Department of Foreign Languages in Professional Communication, \\ 650000, 6 Krasnaya st., Kemerovo, Russian Federation
}

\begin{abstract}
In 2010-2019, we studied the restoration capacity of ecosystems formed on the dumps of coal mines and opencast mining complexes of Kuzbass, Russia. Ant communities were used as indicators of restoration. We found that the restoration of ant assemblages occurs due to ubiquist species, which are replaced by species that predominate in natural cenoses. An increase in the proportion of the latter species is an indicator of restoration of disturbed areas. The fastest restoration process is observed for the forest-steppe zone. In recultivated areas, the restoration of the natural species composition was noted by 30 years of formation, but the density of nests is significantly lower than the control. Uncultivated areas begin to restore only by the age of 35-40.
\end{abstract}

\section{Introduction}

Coal industry still plays a significant role in the global economy. At the same time, the constant demand for raw materials and energy for industrial needs leads to an environmental crisis, especially in those regions in which mining is carried out.

The Kuznetsk coal basin (Kuzbass) is one of the largest coal deposits in the world, located in the south of Western Siberia (Russia). Here, $65 \%$ of the all-Russian volume of coal and $75 \%$ of the volumes of coal of coking grades are mined. Industrial coal mining resulted in excavated areas, waste in the form of overburden dumps, undermined lands. About 450 million tons of overburden and host rocks, more than 14 million tons of coal processing waste, 3 million tons of ash and slag waste are recovered on the surface annually. The area of disturbed lands is at least 91.7 thousand ha. In 2016, the coal industry disturbed 5161.4 ha of soil [1].

Such anthropogenic impact leads to serious changes in the structurally-dynamic organization of ecosystems, including the degradation of biological diversity.

At present, speaking about the advantages and disadvantages of the heat power system, the problems of restoring disturbed lands are being considered first of all. This is especially

\footnotetext{
* Corresponding author: sv blinova@mail.ru
} 
true for Kuzbass, where coal is mined in various ways, which leads to serious changes in the landscape.

Numerous studies show that restoration processes in technologically disturbed areas can be evaluated by various bio-indicator groups (plants, fungi, invertebrate animals, etc.). Often such indicators as changes in numbers, species composition, environmental characteristics and some others are used [2-5].

One of the main components of a natural biocenosis in a temperate climate is ants. In case of any serious disturbances of the habitat, including the disturbances during open and underground mining of minerals and subsequent land reclamation, the species composition and ecological structure of ant assemblages change [6, 7]. Such ecological and biological features of ants allow us to consider them as potential bioindicators of environmental changes $[8,9]$.

The published work is the continuation of a comprehensive long-term research devoted to the study of zoocenoses' restoration on technogenic landscapes formed during coal mining by the enterprises in Kemerovo Region - Kuzbass. So far, the data on the features of the formation of individual groups of herpetobiont mesofauna on the dumps of coal opencasts have been published [10,11]. All of them are important for understanding the existing problem, but insufficient for understanding the severity of degradation of biogeocenoses, and for the targeted adopting a complex of measures to restore technologically disturbed areas.

Restoration processes on dumps of coal mines and opencasts located in various natural zones (forest-steppe and forest) are likely to occur in different ways. Therefore, the aim of this study was to examine the restoration succession of dumps of coal mines and opencasts in Kemerovo Region - Kuzbass on the example of the formation of ant assemblages.

\section{Methods and Materials}

The studies were carried out in May-August 2010-2019 in Kemerovo Region - Kuzbass (Russia). To collect the material, 3 rock dumps of similar formation time (more than 30 years) were identified. Of these, two dumps are located on coal opencasts: the Krasnobrodsky opencast mining complex, which is in the central forest-steppe zone of the Kuznetsk Basin, and the Kedrovsky opencast mining complex - on the border of the northern forest-steppe and plain taiga. The third test dump is located within the coal mine "Ziminka" of Prokopyevsk city, that is also in the forest-steppe zone. In addition, we studied the areas located at the foot of the considered dumps.

The following is a brief description of the studied areas:

Site A1 (The Kedrovsky opencast mining complex, $55^{\circ} 51^{\prime} 39^{\prime \prime} \mathrm{N}, 86^{\circ} 06^{\prime} 17^{\prime \prime} \mathrm{E}$ ) is located at the top of the dump. Here a meadow of grass, with the dominance of Dactylis glomerata, Taraxacum officinale, Centaurea scabiosa, is well developed. At the same time, there is a tree-shrub vegetation represented by Hippophae rhamnoides, Sorbus sibirica and Betula pendula. Woody plants, without forming a closed cover, make up $5 \%$ of the projective cover and are fragmentarily located within the site. Sodding is $20-40 \%$. The projective cover is $90-100 \%$. The recultivation was completed.

Site A2 (55 $\left.{ }^{\circ} 50^{\prime} 75^{\prime \prime} \mathrm{N}, 86^{\circ} 07^{\prime} 94 " \mathrm{E}\right)$ is located at the foot of the previous dump. There the birch forest is developing. Within the site there are open glades with mixed forest meadows, where the height of the grass reaches $1.5 \mathrm{~m}$. Sodding is $20-40 \%$. The projective cover is from $90-100 \%$. The tree layer is Betula pendula, rarely Populus tremula, Salix caprea; the crown density is $30-40 \%$. The shrub layer is represented by Padus avium, Sambucus sibirica, Sorbus sibirica, and Viburnum opulus. The site was not recultivated.

Site B1 (The Krasnobrodsky opencast mining complex, $54^{\circ} 15^{\prime} 66^{\prime} \mathrm{N}, 86^{\circ} 53^{\prime} 12^{\prime \prime} \mathrm{E}$ ) is located on the ledge of the dump terrace. A birch forest is forming in this territory (Betula 
pendula dominates). Sodding is $20-30 \%$. The projective cover of grass cover is from 70 $80 \%$ to $10 \%$ under the crowns of trees, on average for the site it is $50-60 \%$. Calamagrostis epigeios, Cirsium setosum, Fragaria viridis, Melilotus albus prevail in the grass layer. The recultivation was carried out.

Site B2 $\left(54^{\circ} 15^{\prime} 48^{\prime \prime} \mathrm{N}, 86^{\circ} 53^{\prime} 85^{\prime \prime} \mathrm{E}\right)$ is a forming grass-meadow at the foot of the dump. There are individual specimens of woody plants on the site. The grass cover with projective cover up to $85 \%$ (in places about 50-40\%), forms 2 layers. Sodding is not expressed. Mosaic distribution of plants is expressed in the grassy cover; representatives of one species form thickets in separate fragments with an area of up to 3-5 $\mathrm{m}^{2}$. Wood species up to $2 \mathrm{~m}$ high are individually represented within the trial area: Padus avium, Salix caprea, Salix viminalis, Betula pendula, etc. The grassy cover is a complex mosaic of various species, because individual dominants are not expressed. The first layer is composed of Achillea millefolium, Arctium tomentosum, Artemisia vulgaris, and others. The second layer is composed of Achillea asiatica, Aconogonon alpinum, Agrimonia pilosa, etc. The site was uncultivated.

Site C1 (The coal mine "Ziminka", $53^{\circ} 92^{\prime} 52^{\prime \prime} \mathrm{N}, 86^{\circ} 70^{\prime} 61 " \mathrm{E}$ ) is a technological dump formed in the 1960-1980s on the territory of a coal mine. The land recultivation was not carried out. Natural self-growth occurs, as a result of which a grassy-motley meadow formed on its area. The projective coverage is less than $20 \%$. There are single trees of Betula pendula.

Site C2 $\left(53^{\circ} 92^{\prime} 60^{\prime \prime} \mathrm{N}, 86^{\circ} 70^{\prime} 71\right.$ 'E) is a grassy meadow at the base of the dump, where recultivation was carried out. Elytrigia repens, Poa sp., Artemisia absinthium grow there, Padus avium, Betula pendula are also found. The grass height reaches $35 \mathrm{~cm}$. The projective cover is about $50 \%$.

Control sites are located outside the zone of influence of open casts and mines, as well as other technogenic and recreational loads; at the same time, they are located in the same botanical and geographical areas as the studied industrial enterprises.

Site A3 is selected by control for the Kedrovsky opencast mining complex (55 $\circ$ $\left.55^{\prime} 72^{\prime} \mathrm{N}, 86^{\circ} 16^{\prime} 72^{\prime \prime} \mathrm{E}\right)$. This is an area of a sporadic aspen-fir forest with a small admixture of Betula pendula and Picea obovata. A large area (about $80 \%$ ) is occupied by glades with forest tall grass.

Site B3 is control for the Krasnobrodsky opencast mining complex. This is a little forest, untouched by technogenic impact, with open grassy meadows, located $2 \mathrm{~km}$ west of the site $\left(54^{\circ} 14^{\prime} 72^{\prime \prime} \mathrm{N}, 86^{\circ} 49^{\prime} 27^{\prime \prime} \mathrm{E}\right)$. Calamagrostis arundinacea, Calamagrostis epigeios, Calamagrostis obtusata and Cimicifuga foetida predominate in the herbage. The projective coverage is $95-100 \%$. The soil is sod. The crown density of the tree layer is $20-30 \%$; Betula pendula dominates, and Populus tremula and Salix caprea are rarely represented.

Site C3 is control for mine dumps ( $\left.53^{\circ} 89^{\prime} 92^{\prime \prime} \mathrm{N}, 86^{\circ} 54^{\prime} 31^{\prime \prime E}\right)$. It is represented by grassy meadows located about $10 \mathrm{~km}$ against the wind rose from the mine. Poaceae (55-60 $\mathrm{cm}$ high), Prunella vulgaris, Trifolium pratense, Plantago major dominate in the grass. The projective coverage is about $80 \%$.

The species composition and density of ant assemblages were determined by standard myrmecological methods at $10 \times 10 \mathrm{~m}$ test plots. Due to the community lifestyle, extensive fodder area, and uneven distribution in biotopes, Formica s.str. anthills were found on the routes, which were laid throughout the studied site. The obtained data were recalculated per $100 \mathrm{~m}^{2}-$ per one accounting area [6, 11]. Ants were identified by B. Seifert [12], W. Czechowski et al. [13]. Since the ergates of Lasius niger (Linnaeus) and Lasius platythorax Seifert are difficult to distinguish, we consider them as Lasius cf. niger (Linnaeus).

The biotopic groups of ants are identified on the basis of original long-term results of studies of the orographic regions of the Kuznetsk-Salair mountain region. By biotopic groups we mean habitat of a species in the absence of anthropogenic interference (in 
nature).

To compare the species diversity of ants of the studied sites, cluster analysis was used, in which the Simpson index was taken as a measure of similarity. This indicator, based on the relative abundance of species, takes into account the evenness of species and species richness.

Mathematical data processing was performed using Microsoft Excel and Statistica 6.0.

\section{Results and Discussion}

The studies revealed 14 Formicidae species belonging to 5 genera of 2 subfamilies (Tables 1, 2). Camponotus saxatilis nests were found only in the forest-steppe zone, Myrmica schencki and Formica rufa, on the contrary, in the forest zone. Two species of Formicidae (F. aquilonia and F.lugubris) were met only in the control.

Table 1. Species composition and population density of ants in the studied sites, nests $/ 100 \mathrm{~m}^{2}$.

\begin{tabular}{|c|c|c|c|c|c|c|}
\hline \multirow{2}{*}{ Species of ants } & \multicolumn{6}{|c|}{ Sites } \\
\hline & A1 & A2 & $\mathbf{A 3}$ & B1 & B2 & B3 \\
\hline Myrmica rubra (L.) & $\begin{array}{c}0.10 \pm \\
1.32\end{array}$ & & & & & \\
\hline M. ruginodis $\mathrm{Nyl}$. & & $\begin{array}{c}1.20 \pm \\
0.63\end{array}$ & $\begin{array}{c}6.60 \\
\pm 5.4 \\
2\end{array}$ & & + & $\begin{array}{c}2.40 \pm \\
1.95\end{array}$ \\
\hline M. scabrinodis Nyl. & & $\begin{array}{c}1.50 \pm \\
1.43\end{array}$ & & & & \\
\hline M. schencki Vier. & & $\begin{array}{c}0.40 \pm \\
0.84\end{array}$ & & & & \\
\hline Tetramorium caespitum L. & $\begin{array}{c}0.60 \pm \\
0.97\end{array}$ & & & $\begin{array}{c}2.00 \pm \\
1.49\end{array}$ & $\begin{array}{c}0.40 \pm \\
0.52\end{array}$ & + \\
\hline Camponotus saxatilis Ruzs. & & & & $\begin{array}{c}1.00 \pm \\
0.67\end{array}$ & $\begin{array}{c}1.60 \pm \\
0.52\end{array}$ & $\begin{array}{c}1.60 \pm \\
1.08\end{array}$ \\
\hline Formica aquilonia Yarr. & & & + & & & \\
\hline F. glauca Ruzs. & & & ++ & $\begin{array}{c}0.40 \pm \\
0.52\end{array}$ & $\begin{array}{c}0.40 \pm \\
0.52\end{array}$ & \\
\hline F. fusca L. & & $\begin{array}{c}1.50 \pm \\
1.08\end{array}$ & $\begin{array}{c}0.20 \\
\pm 0.4 \\
2\end{array}$ & & $\begin{array}{c}2.00 \pm \\
2.21\end{array}$ & $\begin{array}{c}3.20 \pm \\
2.35\end{array}$ \\
\hline F. lugubris Zett. & & & ++ & & & \\
\hline F. pratensis Retz. & & & & & + & ++ \\
\hline F. rufa L. & & + & & & & \\
\hline F. rufibarbis Fabr. & ++ & & & $\begin{array}{c}2.00 \pm \\
0.94\end{array}$ & & \\
\hline Lasius flavus $\mathrm{F}$. & $\begin{array}{c}0.40 \pm \\
0.69\end{array}$ & $\begin{array}{c}1.50 \pm \\
1.08\end{array}$ & & $\begin{array}{c}6.00 \pm \\
2.58\end{array}$ & $\begin{array}{c}0.80 \pm \\
0.03\end{array}$ & + \\
\hline L. cf. niger (L.) & $\begin{array}{c}1.70 \pm \\
0.48\end{array}$ & & $\begin{array}{c}0.20 \\
\pm 0.4 \\
2\end{array}$ & $\begin{array}{c}3.00 \pm \\
1.76\end{array}$ & $\begin{array}{c}2.40 \pm \\
2.88\end{array}$ & $\begin{array}{c}0.80 \pm \\
0.79\end{array}$ \\
\hline Number of species & 5 & 6 & 6 & 6 & 8 & 7 \\
\hline Average population density & $\begin{array}{c}2.80 \pm \\
0.88\end{array}$ & $\begin{array}{c}5.00 \pm \\
1.11\end{array}$ & $\begin{array}{c}7.00 \\
\pm 4.3 \\
2\end{array}$ & $\begin{array}{c}14.40 \pm 1 \\
.27\end{array}$ & $\begin{array}{c}7.60 \pm \\
5.02\end{array}$ & $\begin{array}{c}8.0 \pm 2 . \\
495\end{array}$ \\
\hline
\end{tabular}

Note: + only working individuals found without a nest; ++ nests found in faunal studies; see in text. 
Table 2. Species composition and population density of ants in the studied sites of the mine, nests / $100 \mathrm{~m}^{2}$.

\begin{tabular}{|l|c|c|c|}
\hline \multirow{2}{*}{ Species of ants } & \multicolumn{3}{c|}{ Sites } \\
\cline { 2 - 4 } & C1 & C2 & C3 \\
\hline M. scabrinodis Nyl. & & $0.20 \pm 0.41$ & $1.20 \pm 1.13$ \\
\hline Tetramorium caespitum L. & & $0.80 \pm 0.92$ & $5.00 \pm 2.36$ \\
\hline Formica glauca Ruzs. & & & $0.40 \pm 0.70$ \\
\hline F. fusca L. & & $0.20 \pm 0.42$ & + \\
\hline F.rufa L. & & & $4.50 \pm 2.72$ \\
\hline Lasius flavus F. & & $0.70 \pm 1.49$ & 6 \\
\hline L. cf. niger (L.) & $0.50 \pm 0.527$ & $2.30 \pm 1.42$ & $11.60 \pm 4.53$ \\
\hline Число видов & 1 & 5 & $22.70 \pm 4.74$ \\
\hline Average population density & $0.50 \pm 0.527$ & $4.20 \pm 1.27$ & \\
\hline Note: + only working individuals without a nest were found \\
\hline
\end{tabular}

Obviously, in general, on the recultivated dumps and control sites, an almost equal number of ants were found. However, the density of nests and their location over the sites are noticeably different: on the dumps of coal opencasts, a more even distribution of nests over the study site compared to the control is noted. In contrast, in natural cenoses (control), nests are located predominantly aggregated. Most likely, this can be explained by the presence of Formica s. str. (red wood ants): F. lugubris, F. pratensis, F. rufa. As it is known $[14,15]$, these species have a significant protected area, thereby affecting the distribution of nests of other species in the biotope.

On old mine dumps (C1) (uncultivated), no ant nests were found. Gradual ants' colonization of such areas occurs 35-40 years after their formation. Moreover, in the first 10 years only monospecies $L$. $c f$. niger are found; all nests are located in the substrate. On dumps formed 35-40 years ago, the population density reached $0.30 \pm 0.483$ nests $/ 100 \mathrm{~m}^{2}$, on $45-50$-year-old dumps $-0.40 \pm 0.516$ nests $/ 100 \mathrm{~m}^{2}$, and over 50 years, $-0.50 \pm 0.527$ nests / $100 \mathrm{~m}^{2}$.

In general, the density of ant assemblages in the uncultivated sites of the dumps of the coal opencasts and in the control is comparable, and the recultivated sites, on the contrary, are markedly different (Table 1). In our opinion, this is due to the difference in restoration succession between mine dumps and opencast dumps, which is primarily due to the technology of restoration: technological dumps of mines are recultivated only at the foot, creating a normal environment for humans. The size of such dumps, located directly within the boundaries of human settlements, is relatively small; while the dump itself is left without recultivation. Dumps formed as a result of coal opencasts, on the contrary, are usually recultivated from the very top, leaving the foot without recultivation. Natural biotopes adjoin these areas, as a result of which there is an active population of species from adjacent areas.

It is interesting to note that the nests of $F$. rufibarbis were recorded only in the recultivated sites of the opencasts (A1 and B1). All the nests found are aggregated in open areas with low design coverage (up to $30 \%$ ). With an increase in the area of the projective cover, F. rufibarbis does not occur. It is noteworthy that the size of the breed, compared with the other areas of the region, is relatively large. In addition, a tendency of Tetramorium caespitum nests to the settlement of the previous species was found.

Our previous long-term ecological-faunal studies of Formicidae in the Kuznetsk-Salair mountain region allowed us to describe the biotopic preferences of all the species found:

- ubiquist species whose settlements are registered in various types of forests, meadows, in steppe and steppe areas. These are C. saxatilis, F. fusca, L. flavus, L. cf. niger;

- meadow-forest species that settle in forests and grassy meadows: Myrmica rubra, $M$. schencki, M. scabrinodis, F. pratensis, F. rufa; 
- forest species whose nests are found only in various types of forests: M. ruginodis, $F$. aquilonia, F. glauca, F. lugubris;

- meadow-steppe species whose nests are found on various types of meadows and steppes:

T. caespitum, F. rufibarbis.

The distribution of biotopic groups in the studied sites is shown in Fig. 1.

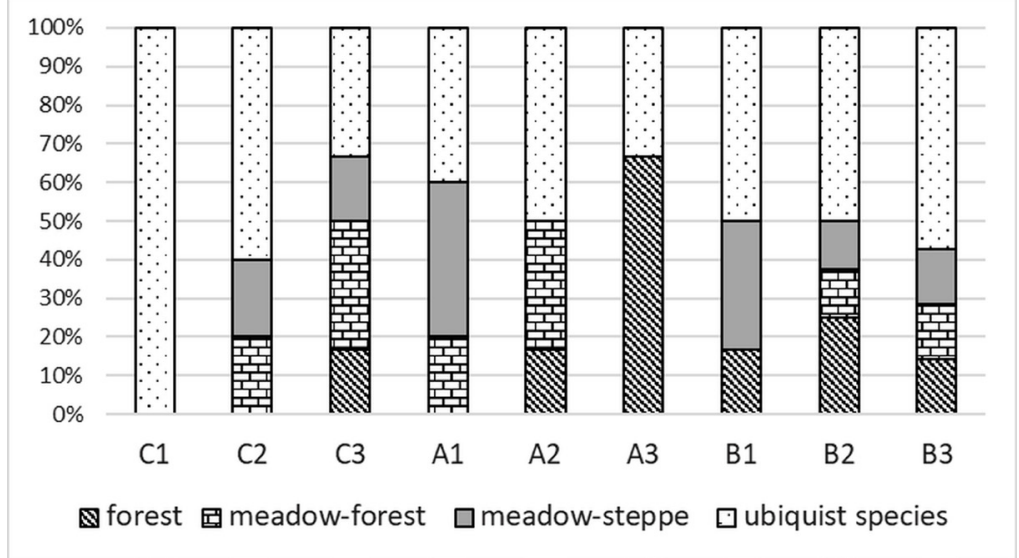

Fig. 1. Representation of biotopic groups in the studied sites, see in text.

Obviously, the restoration of meadow lands in the forest-steppe zone occurs primarily due to eurytopic species. This is particularly evident in uncultivated sites (C1, A2). Gradually, the share of these species decreases (from 100\% in uncultivated sites to $33 \%$ in the control), giving way to meadow, meadow-forest and meadow-steppe species. It should be noted that on uncultivated dumps located in the forest-steppe zone, even after 30 years, species of the meadow and meadow-steppe groups do not settle.

The restoration processes at the dumps of the Kedrovsky opencast, located in the forest zone, differ: here, in uncultivated areas, the proportion of meadow, meadow-forest and meadow-steppe species is relatively high $(50 \%)$. At the recultivated dumps, the proportion of the latter sharply increases (up to $32.3 \%$ ) at first, but at the same time in the control it is less than $15 \%$. It has been established that after recultivation, meadow and forest-steppe biocenoses are formed much faster. In such areas, the proportions of eurytopic and meadow-steppe species decrease or the latter completely disappear; the proportion of meadow-forest species increases first, and then the proportion of forest species increases. However, the forest-steppe nature of zonal vegetation in site B3 (control of the Krasnobrodsky opencast), in our opinion, leads to a somewhat different picture of the recovery of the ant assemblages. So, in the control, a high proportion of meadow-steppe and meadow-forest species was found, compared with the recultivated sites of dumps.

Thus, an increase in the proportion of ants belonging to the meadow-steppe and meadow-forest biotopic groups can be considered the indicators of ongoing restoration succession for dumps in the forest-steppe zone of Kuzbass. On the contrary, in the forest zone (the Kedrovsky opencast mining complex), an increase in the proportion of forest species is an indication of the restoration of a technologically disturbed area.

To compare the structure of the ant communities of the studied sites, a dendrogram based on the Simpson similarity indices was constructed. Figure 2 shows that site C1, which is characterized by the poorest species composition, is the first to sharply separate from the common tree. Recall that only $L$. cf. niger was found there. This trend is well founded, because the recultivation was not carried out on this area, and the existing conditions do not allow most species of ants to settle on it. 
The second separate cluster branch is formed by site A2 located at the foot of the dump, as well as site A3, similar in species composition of ants. The reason for this may be the fact that in site A2 there is an active development of birch forest with typical forest vegetation. This creates favourable conditions for the habitat of meadow-forest and forest species, as it is in the control with a sporadic aspen-fir forest. The data obtained show us that the recovery of ant assemblages in the uncultivated areas of the Kedrovsky opencast located in the forest zone is much faster than in recultivated areas, which coincides with the other data [10].

The following groups on the cluster form the sites of dumps of the mine and the Krasnobrodsky opencast. It is interesting to combine the sites located on the dumps of the considered opencasts. And it should be noted that they are located in different natural zones of the Kuznetsk Basin. The isolation of these sites is probably due to the fact that they are similar in microclimatic characteristics and type of vegetation, which contribute to a significant settlement of these areas with species that prefer open habitats. The data obtained indicate that the restoration of ant assemblages in technologically disturbed territories primarily depends on the nature of the emerging phytocenosis.

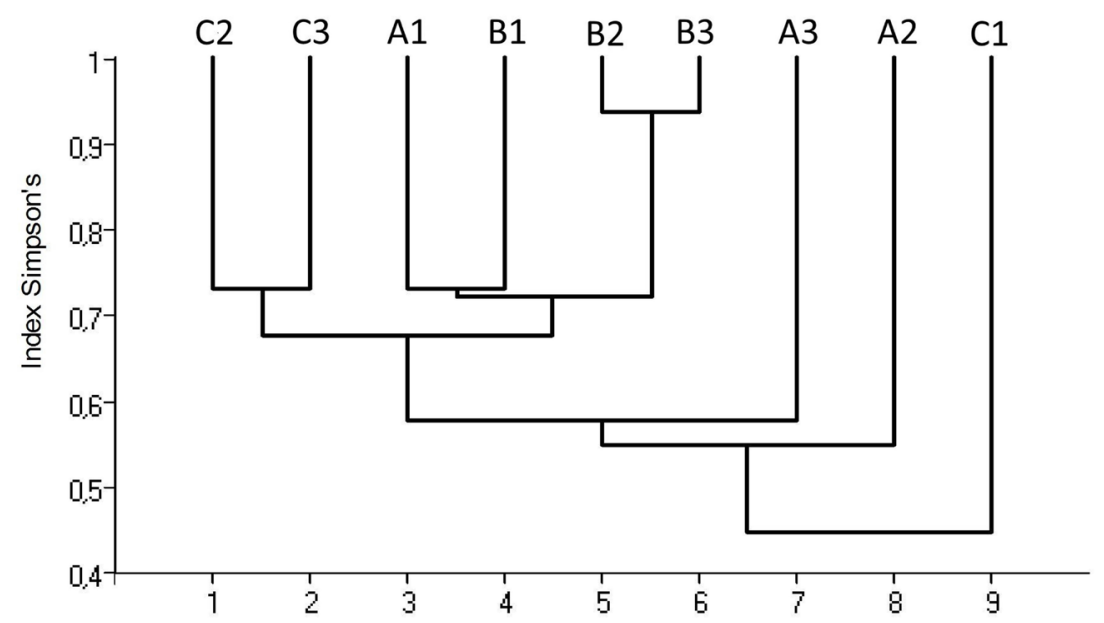

Fig. 2. Dendrogram of similarity of the studied sites on the Simpson index, see in text.

\section{Conclusion}

Thus, the results reinforce further developing methods for biological assessment of the degree of recovery of anthropogenically transformed ecosystems, considering such indicators as the species composition and density of settlements, the ratios of Formicidae groups by biotopic confinement. Indicators of ongoing recovery succession for dumps in the forest-steppe zone of Kuzbass can be considered an increase in the proportion of species of meadow-steppe and meadow-forest ants; in the forest zone, it is an increase in the proportion of forest species. Judging by ant assemblages, the recovery of natural cenosis occurs faster on dumps in the forest-steppe zone. 


\section{References}

1. S. Burtsev, V. Efimov, T. Korchagina, E3S Web Conf. 21, 02017 (2017)

2. J. Frouz, Soil biota and ecosystem development in post mining sites (Penguins, London, 2013)

3. D. Buchori, A. Rizali, G. A. Rahayu, I. Mansur, Biodiversitas, 19, 5 (2018)

4. E. Belskaya, A. Gilev, E. Belskii, Environ. Sci. Pollut. Res., 24, 11 (2017)

5. E. Belskaya, A. Gilev, M. Trubina, E. Belskii, Ecological Indicators, 106, 105447 (2019)

6. M. Holec, J. Frouz, Pedobiologia, 49, 4 (2005)

7. L. Ottonetti, L. Tucci, G. Santini, Restoration Ecology, 14, 1 (2006)

8. J. D. Majer, Environmental Management, 7, 41983

9. M. J. Lawes, A. M. Moore, A. N. Andersen, N. D. Preece, D. C. Franklin, Ecol. Evol., 7, 20 (2017)

10. L. Trilikauskas, S. Luzyanin, E3S Web Conf., 41, 02021 (2018)

11. S. Blinova, M. Korchagina, A. Radosteva, T. Dobrydina, E3S Web Conf., 41, 02024 (2018)

12. B. Seifert, Abh. Ber. Naturkundemus. Görlitz, 66, 5 (1992).

13. W. Czechowski, A. Radchenko, W. Czechowska, The ants (Hymenoptera, Formicidae) of Poland (MIZ, Polish Academy of Sciences, Warszawa, 2002)

14. B. Hölldobler, E. O. Wilson, The Ants (Springer, Berlin, 1990)

15. A. A. Zakharov, Entmol. Rev., 95, 8 (2015) 